\title{
SENANDUNG MENIDURKAN ANAK SEBAGAI UPAYA PENANAMAN NILAI-NILAI PENDIDIKAN KARAKTER TERHADAP ANAK
}

\author{
LULLABY AS EFFORT TO IMPLEMENT \\ CHARACTER BUILDING VALUES TO THE CHILDREN
}

\author{
Marlina \\ Balai Bahasa Riau \\ marlinabbpku@gmail.com
}

\begin{abstract}
ABSTRAK
Penelitian ini bertujuan mendeskripsikan dan menganalisis nilai-nilai pendidikan karakter yang terdapat di dalam senandung menidurkan anak pada masyarakat Melayu Siak di Riau. Masalah penelitian adalah nilai-nilai pendidikan karakter apa saja yang terdapat di dalam senandung menidurkan anak pada masyarakat Melayu Siak. Untuk menemukan nilai-nilai pendidikan karakter yang terdapat di dalam senandung menidurkan anak tersebut, digunakan metode deskriptif kualitatif, yakni metode yang memaparkan tulisan berdasarkan isi senandung menidurkan anak. Hasil penelitian membuktikan bahwa senandung menidurkan anak mengandung nilai keimanan dan ketakwaan, kecerdasan, kesusilaan dan budi pekerti. Dari hasil penelitian tersebut dapat disimpulkan bahwa senandung menidurkan anak dapat dijadikan sebagai alat penanaman nilai pendidikan karakter terhadap anak.
\end{abstract}

Kata Kunci: senandung, anak, nilai, pendidikan, karakter

\begin{abstract}
This study aims to describe and analyze the values of character education contained in the lullaby of Siak Malay community in Riau. The research problem is what character education values contained in the lullaby in the Siak Malay community. To find the values of character education contained in the lullaby, the qualitative descriptive method is used, which is a method that exposes writing based on the content of the lullaby. The result of the study shows that the lullaby contains the value of faith and piety, intelligence, morality and character. From the results of this study, it can be concluded that the lullaby can be used as a tool to implement the value of character education for children.
\end{abstract}

Keywords: lullaby, children, value, education, character

\section{PENDAHULUAN}

Perkembangan zaman tidak hanya berpengaruh kepada kemajuan teknologi, kemajuan di bidang ekonomi ataupun kemajuan di bidang ilmu pendidikan. Perkembangan zaman tidak bisa dipungkiri telah berimbas kepada segala sendi kehidupan masyarakat negeri ini. Salah satunya adalah perubahan pada sikap dan tingkah laku anak-anak. Kenakalan remaja seperti tawuran, ketergantungan kepada narkoba, dan pergaulan bebas telah menjadi tontonan sehari-hari saat ini. Semua ini terjadi karena melemahnya nilai-nilai luhur bangsa, kurangnya 
pemahaman etika di tengah-tengah masyarakat dan semakin minimnya pendidikan karakter bagi anak-anak kita.

Anak-anak tidak lagi memiliki sifat santun dan hormat kepada orang tua, guru, ataupun kepada orang-orang yang lebih tua. Rasa belas asih generasi muda masa sekarang semakin menipis, bahkan hilang sama sekali. Pengaruh lingkungan dan kemajuan teknologi seperti gadget telah melunturkan berbagai karakter kebaikan yang melekat pada diri seorang anak. Oleh sebab itu, dibutuhkan pendidikan karakter untuk menanamkan nilai-nilai kebaikan dan nilai-nilai kebenaran ke dalam diri anak-anak.

Pendidikan karakter menjadi usaha yang paling efektif untuk mengatasi berbagai permasalahan yang muncul di kalangan pelajar, bahkan pendidikan karakter sudah menjadi ikon pendidikan di Indonesia. Penanaman nilai-nilai karakter ini harus dilakukan sejak dini agar anak-anak memiliki pondasi yang kuat ketika mereka telah beranjak remaja hingga dewasa kelak. Pembentukan karakter dapat melalui pendidikan budi pekerti yang melibatkan aspek pengetahuan, perasaan dan tindakan. Pendidikan karakter diharapkan dapat membangun pribadi anak menjadi pribadi yang baik dan berbudi pekerti luhur yang diwujudkannya dalam kehidupan sehari-hari.

Senandung menidurkan anak bisa menjadi salah satu pilihan dalam menanamkan nilai-nilai pendidikan karakter pada anak. Senandung menidurkan anak adalah nyanyian yang dilagukan untuk menidurkan anak atau mengayun anak. Secara umum, orang menyebut lagu ini dengan sebutan nina bobo. Senandung menidurkan anak mempunyai lagu dan irama yang halus tenang, berulang-ulang, ditambah dengan kata-kata kasih sayang sehingga dapat membangkitkan rasa santai dan akhirnya mendatangkan rasa kantuk pada anak yang mendengarnya (Danandjaja, 1994:146). Selain kata-kata kasih sayang, dalam senandung ini ditambahkan kata-kata berupa bujukan, nasihat, doa, dan harapan orang tua pada anaknya.

Dalam kehidupan masyarakat Siak sudah lama dikenal tradisi mengayun anak. Mengayun anak dalam keseharian adalah untuk menidurkannya, karena dengan diayun si anak akan tertidur pulas. Sehari-hari, ibu-ibu di Kabupaten Siak itu menidurkan anaknya dengan cara mengayun. Mereka bisa mengayun anak sambil berdendang. Seorang ibu akan bernyanyi dengan suara merdu dan mendayu-dayu. Lirik lagunya sangat puitis dan biasanya penuh petuah. Senandung menidurkan anak juga bisa menjadi perekat hubungan fisik dan batin antara seorang ibu dengan anaknya. Selain itu, senandung menidurkan anak juga berisi kalimat-kalimat yang memiliki nilai-nilai kebaikan untuk seorang anak. Senandung menidurkan anak berisi kalimat-kalimat tauhid, kalimat-kalimat nasihat, doa dan pengharapan seorang ibu kepada anaknya.

Senandung menidurkan anak merupakan salah satu sastra lisan yang masih cukup dikenal oleh masyarakat di Siak. Sastra lisan merupakan salah satu bagian dari tradisi lisan. Ansor (Neldawati dkk, 2015:72) mengungkapkan bahwa sastra lisan disebarkan dari satu orang ke orang lain sehingga menjadi sebuah tradisi yang berkembang di tengah kelompok masyarakat dengan menggunakan bahasa sebagai mediumnya. 
Sastra lisan memiliki perbedaan dengan sastra tulis. Hal yang membedakan antara keduanya bisa dilihat dari ciri sastra lisan yang diungkapkan oleh Amir (2013:78) yang meliputi: (1) sastra lisan ada dalam wujud pertunjukkan, dalam banyak kasus diiringi instrumen bunyi-bunyian, bahkan tarian; (2) unsur hiburan dan pendidikan dominan di dalamnya; (3) menggunakan bahasa setempat, bahasa daerah, paling tidak dialek daerah, dan (4) menggunakan puitika masyarakat bahasa itu.

Sementara menyangkut fungsi, sastra lisan memiliki beberapa manfaat dan kegunaan bagi masyarakat Melayu Riau. Dainuddin (Neldawati dkk, 2015:72) mengungkapkan fungsi sastra lisan bagi pemakainya dalam kehidupan masyarakat Melayu Riau adalah sebagai: (a) untuk menyampaikan suatu nasihat atau ajaran agama secara ungkapan, (b)saraana dalam menyampaikan adat dan aturan-aturan dalam kehidupan masyarakat, (c) sebagai pengisi waktu lowong, (d) sebagai hiburan, (e) sarana penyampai pendidikan, (f) sarana penyampain kasih sayang, (g) sarana komunikasi dalam penyampain perasaan cinta, rasa benci, rasa gembira, (h) sarana dalam menidurkan anak, (i) sebagai alat untuk berpikir seperti pantun dan teka-teki, serta (j) sebagai bahan renungan seperti syair yang ada kaitannya dengan keagamaan dan cerita-cerita yang mempertentangkan kebaikan dan keburukan.

Sastra lisan yang diangkat dalam penelitian ini adalah nyanyian menidurkan anak yang terdapat di Kabupaten Siak. Tradisi lisan ini merupakan bagian dari tradisi yang berkembang di kehidupan masyarakat yang menggunakan bahasa sebagai media utama. Dalam kehidupan sehari-hari, jenis sastra ini biasanya dituturkan oleh seorang ibu kepada anaknya. Untuk menjaga kelangsungan sastra lisan ini, warga masyarakat mewariskannya secara turuntemurun dari generasi ke generasi.

Nyanyian menidurkan anak tergolong pada nyanyian rakyat, yakni bentuk tradisi lisan yang terdiri atas kata-kata dan lagu yang beredar secara lisan di antara anggota kolektif tertentu, berbentuk tradisional, serta banyak mempunyai varian (Danandjaja,1994:141). Bila dilihat lebih khusus lagi, dendang menidurkan anak ini termasuk dalam golongan nyanyian rakyat yang berfungsi. Disebut berfungsi karena irama lagu dan syairnya cocok dengan aktivitas yang menjadi tujuan khusus nyanyian ini, seperti tidur, bekerja, atau bermain (Danandjaja, 1994:146).

Menurut Brunvand (Danandjaja, 1994) nyanyian rakyat terdiri dari tiga jenis yaitu: 1) nyanyian rakyat yang berfungsi yaitu nyanyian rakyat yang kata-kata dan lagunya memegang peranan yang sama penting, contoh: nyanyian kelonan/menidurkan anak (lullaby), nyanyian kerja (working song), dan nyanyian permainan (playing song); 2) nyanyian rakyat yang bersifat liris yaitu nyanyian rakyat yang teksnya bersifat liris, yang merupakan pencetusan rasa haru pengarangnya; dan 3) nyanyian rakyat yang bersifat berkisah (narrative song).

Seperti halnya tradisi lisan yang lain, senandung menidurkan anak juga mengandung nilai-nilai kebaikan dan nilai-nilai pendidikan karakter. Pendidikan karakter menurut Lickona (2012:81) mengandung tiga unsur pokok, yaitu mengetahui kebaikan, mencintai kebaikan, dan melakukan kebaikan. Sementara karakter yang baik terdiri dari mengetahui hal yang baik, menginginkan hal yang 
baik dan melakukan hal yang baik, kebiasaan dalam cara berpikir, kebiasaan dalam hati, dan kebiasaan dalam tindakan.

Sementara menurut Wibowo (Muttakin, 2015:29) karakter identik dengan akhlak, sehingga karakter merupakan nilai-nilai perilaku manusia yang universal yang meliputi seluruh aktivitas manusia, baik dalam rangka berhubungan dengan Tuhan, diri sendiri, sesama manusia, maupun dengan lingkungan. Semuanya itu terwujud dalam pikiran, sikap, perasaan, perkataan, dan perbuatan berdasarkan norma-norma agama, hukum, tata karma, budaya dan adat istiadat.

Pendidikan karakter menurut Maksudin (Muttakin, 2015:29) perlu dibentuk pada anak dengan beberapa alasan; (1) Karakter adalah bagian esensial manusia dan karenanya harus diajarkan, (2) Saat ini karakter generasi mudah mengalami erosi, pudar, dan kering keberadaannya; (3) Terjadi detolisasi kehidupan yang diukur dengan uang yang didapatkan dengan menghalalkan segala cara, (4) Karakter merupakan salah satu bagian manusia yang menentukan kelangsungan hidup dan perkembangan warga, baik Indonesia maupun dunia.

Pendidikan karakter mempunyai makna lebih tinggi dari pendidikan moral, karena bukan sekadar mengajarkan mana yang benar dan mana yang salah, tetapi lebih dari itu karena pendidikan karakter menanamkan kebiasaan tentang hal yang baik sehingga anak-anak menjadi paham tentang mana yang benar dan salah, serta mampu merasakan nilai yang yang baik dan mau melakukannya (Sudaryanto, 2012:14).

Menurut Lason dalam Muttakin (2015:30) ada tiga bidang yang saling berhubungan dalam pendidikan karakter yang baik. Ketiga bidang tersebut yaitu diri sendiri, orang lain dan masyarakat. karakter anak yang dapat dilihat dalam diri sendiri yaitu karakter disiplin, tanggung jawab, percaya diri, dan keberanian. Adapun karakter yang berhubungan dengan orang lain dan masyarakat yaitu kejujuran, rasa hormat, empati, kebaikan, dan dapat bersosialisasi dengan teman, guru dan keluarga.

Prayitno dan Afriva (2013:130-139) merumuskan lima fokus nilai-nilai pendidikan yang bersumber dari pengembangan komponen/unsur-unsur harkat dan martabat manusia dan nilai-nilai Pancasila. Nilai-nilai pendidikan karakter tersebut, yaitu: (1) Keimanan dan ketakwaan kepada Tuhan Yang Maha Esa, (2) Kejujuran, (3) Kecerdasan, (4) Ketangguhan, (5) Kepedulian.

Sementara menurut Shimpey (Nasir, 2016:5) nilai pendidikan dapat dibagi atas nilai tanggung jawab, nilai ketakwaan kepada Tuhan, nilai kemandirian, nilai kecerdasan, nilai keterampilan, nilai hedonik, nilai kultural, dan nilai praktis. Sedangkan Titarahardja dan Sulo dalam Nasir (2016:5) dalam pemahaman dan pelaksanaan nilai membagi dua dimensi atau nilai pendidikan, yaitu: (a) Nilai pendidikan kesusilaan, kesadaran dan kesediaan melakukan kewajiban di samping menerima hak; (b) Nilai pendidikan agama, merupakan kebutuhan manusia karena manusia adalah makhluk hidup yang lemah sehingga memerlukan tempat bertopang yakni Tuhan. Manusia memerlukan agama demi keselamatan hidupnya.

Berdasarkan uraian tentang nilai-nilai pendidikan karakter dari beberapa ahli di atas, dapat disimpulkan bahwa nilai pendidikan karakter yang terdapat di dalam nyanyian menidurkan anak yang terdapat pada masyarakat nusantara adalah (a) Nilai karakter religius, (b) Nilai Karakter kesusilaan/budi pekerti, (c) Nilai 
karakter kecerdasan, (d) Nilai karakter sosial, (e) Nilai karakter kesabaran, (f) Nilai karakter kemandirian.

Beberapa penelitian telah mengangkat tentang nilai-nilai pendidikan karakter yang terdapat di dalam tradisi lisan. Seperti penelitian yang dilakukan oleh Salahuddin dkk yang berjudul "Nilai-Nilai Pendidikan Karakter Syair Nyanyian Rakyat Maondu Pojo di Kecamatan Kapur IX Kabupaten Lima Puluh Kota" (2015). Analisisnya menyimpulkan bahwa nyanyian rakyat Maondu Pojo memiliki nilai karakter yang terdiri dari nilai keimanan/ketakwaan, kejujuran, kecerdasan, ketangguhan dan kepedulian.

Neldawati dkk juga telah melakukan penelitian yang berjudul "Nilai-Nilai Pendidikan Karakter dalam Pantun Badondong Masyarakat Desa Tanjung Bungo Kecematan Kampar Timur Kabupaten Kampar" (2015). Penelitian ini menyimpulkan bahwa pantun badondong mengandung nilai pendidikan karakter yang berhubungan dengan Tuhan, nilai pendidikan karakter yang berhubungan dengan diri sendiri, yang berhubungan dengan sesama dan yang berhubungan dengan lingkungan. Febrianti (2017) menulis tentang "Pendidikan Karakter Anak dalam Cerita Kancil dan Siput (Seri Cerita Rakyat Dayak Kanayatn Kalimantan Barat). Analisisnya menyimpulkan bahwa cerita anak Dayak Kanayat pendidikan karakter dalam cerita Kancil dan Siput.

Untuk itu, penulis merasa tertarik untuk mengetahui nilai-nilai pendidikan karakter yang terdapat di dalam Nyanyian Senandung Menidurkan Anak yang terdapat di Kabupaten Siak, Riau. Sebab sepengetahuan penulis, belum banyak pembahasan tentang nilai-nilai pendidikan karakter yang terdapat di dalam syair senandung menidurkan anak.

Permasalahan dalam penelitian ini adalah nilai-nilai pendidikan karakter apa saja yang terdapat di dalam syair senandung menidurkan anak di Siak. Sementara tujuan dari penelitian ini adalah menganalisis dan mendeskripsikan nilai-nilai pendidikan karakter yang terdapat di dalam syair senandung menidurkan anak di Siak. Diharapkan penelitian ini memiliki konstribusi bagi bagi masyarakat Siak dan bagi dunia pendidikan di Siak. Diharapkan senandung menidurkan anak dijadikan sebagai bahan ajar pendidikan karakter pada anak di sekolah.

\section{METODE}

Metode yang digunakan dalam penelitian ini adalah metode deskriptif kualitatif. Ratna (2012:47) mengemukakan bahwa penelitian kualitatif memberikan perhatian terhadap data alamiah, data dalam hubungannya dengan konteks keberadaannya. Metode kualitatif melibatkan sejumlah besar gejala sosial yang relevan. Sesuai dengan namanya, penelitian kualitatif mempertahankan nilainilai. Sementara untuk sumber datanya adalah karya, naskah, data penelitian dan data formalnya adalah kata-kata, kalimat dan wacana.

Masih menurut Ratna (2012:47-48), ciri terpenting metode kualitatif adalah: (1) Memberikan perhatian utama pada makna dan pesan, sesuai dengan hakikat objek, yakni sebagai studi kultural; (2) Lebih mengutamakan proses dibandingkan dengan hasil penelitian sehingga makna selalu berubah; (3) Tidak ada jarak antara subjek peneliti dengan objek peneliti, subjek peneliti sebagai instrumen utama, sehingga terjadi interaksi langsung antara keduanya; (4) Desain dan kerangka 
penelitian bersifat sementara sebab penelitian bersifat terbuka; (5) Penelitian bersifat alamiah, terjadi dalam konteks sosial budaya masing-masing.

Jenis dan sumber data penelitian ini adalah syair senandung menidurkan anak yang diperoleh dari syair yang dinyanyikan oleh informan (Ibu Winda Harniati pada tanggal 9 hingga 12 Februari 2017, di Kecamatan Mempura, Kabupaten Siak). Senandung ini kemudian direkam menggunakan alat perekam. Selanjutnya data yang diperoleh ditranskripsikan dalam bentuk kata dan kalimat secara tertulis.

Teknik pengumpulan data yang dilakukan peneliti terdiri dari beberapa bagian yang meliputi: (1) teknik observasi; (2) wawancara; (3) perekaman; (4) pencatatan: (5) klasifikasi data; (6) analisis data. Teknik analisis data yang digunakan dalam penelitian adalah analisis teks dan analisis model interaktif yang dikembangkan oleh Miles dan Humberman dalam Al-Afandi (2015:83), bahwa analisis model interaktif ini meliputi tiga komponen penting yang selalu bergerak, yaitu reduksi data, penyajian data, dan penarikan simpulan/verifikasi. Analisis model interaktif dapat dijelaskan sebagai berikut.

1. Data lisan senandung menidurkan anak (Siak) yang diperoleh yang diperoleh dari hasil wawancara dan observasi di lapangan serta data-data tertulis, dikumpulkan kemudian dilakukan transfer data dengan memindahkan data lisan syair senandung menidurkan anak (Siak) ke dalam bentuk tulisan.

2. Analisis yang dilakukan berupa kata-kata dan kalimat dalam syair senandung menidurkan anak difokuskan pada nilai-nilai pendidikan karakter.

3. Hasil analisis nilai pendidikan karakter yang ditemukan di dalam teks syair dikelompokkan berdasarkan jenis nilai-nilai yang terkandung di dalam syair senandung menidurkan anak tersebut.

4. Penyajian data teks syair senandung menidurkan anak (Siak) diorganisasikan berdasarkan nilai yang disusun secara berurutan untuk dijadikan landasan sebagai kesimpulan akhir.

\section{PEMBAHASAN}

Lirik senandung menidurkan anak mengemban fungsi direktif karena termasuk genre sastra yang dimanfaatkan oleh masyarakat pada zaman dahulu yang menggunakan lirik lagu di saat menidurkan anaknya sebagai media untuk menyampaikan pesan, nasihat, doa dan permohonan, pendidikan dan ajaran-ajaran tentang nilai-nilai kebenaran.

Lirik lagu ini juga berfungsi sebagai penanaman karakter pada anak, mengajarkan kepada anak supaya berbuat baik, rajin belajar dan membantu orang tua. Hal ini berkaitan dengan karakter fungsinya yang juga positif, yakni sebagai media pendidikan, pedoman tingkah laku (norma), dan pengaturan aspek-aspek kehidupan pada masyarakat Melayu.

Fungsi lirik lagu menidurkan anak pada tulisan ini juga dianggap sebagai media yang tepat untuk melakukan pembinaan mental, pendidikan secara informal sejak dini kepada anak-anak dan cucunya. Ini bisa dilihat dari isi lirik lagu menidurkan anak yang mengisahkan cerita nabi, kearifan, dan contoh-contoh mengenai kehidupan dapat memberikan nilai-nilai atau norma tentang agama, akhlak, budi pekerti dan moral. 
Fungsi lirik lagu sebagai media pendidikan, yakni sebagai pedoman tingkah laku dan pengatur aspek-aspek kehidupan. Pengajaran nilai-nilai luhur dimaksud dilakukan secara tidak langsung melalui nyanyian lirik lagu menidurkan anak berkonotasi nasihat, petuah dan pesan-pesan moralitas atau etika sosial yang dapat dijadikan sebagai pedoman hidup dan pengarah tingkah laku anak sebagai bagian dari masyarakat atau orang perorang.

\section{Nilai Pendidikan Karakter di dalam Syair Senandung Menidurkan Anak di Siak}

\section{Nilai Pendidikan Karakter Keimanan dan Ketakwaan}

Nilai pendidikan karakter keimanan dan ketakwaan berhubungan dengan nilai religius yang mengikat dan mengatur manusia dengan Tuhannya atau agamanya. Nilai pendidikan karakter yang berhubungan dengan Tuhan dinyatakan dengan sikap beriman dan bertakwa.

Masyarakat Melayu merupakan masyarakat yang taat dalam beragama. Segala sendi kehidupan masyarakatnya mencerminkan perilaku seorang muslim yang berpegang teguh pada agama. Syair Senandung Menidurkan Anak yang terdapat di Siak mengandung nilai-nilai pendidikan karakter keimanan dan ketakwaan, yakni pengakuan akan keesaan Allah dan pengakuan bahwa nabi Muhammad adalah utusan Allah. Seperti kutipan syair di bawah ini.

\section{Laillahaillalloh .... \\ Muhammad kekasih Allah \\ Muhammad kekasih Allah \\ Laillahaillallah ... \\ Muhammad kekasih Allah \\ Laillahaillallah ... \\ Nabi Muhammad kekasih Allah (Harniati, 2017).}

Senandung menidurkan anak di Siak, pada umumnya selalu diawali dengan kalimat tauhid, yaitu kalimat Laillahaillallah, tiada Tuhan selain Allah. Kalimat ini menunjukkan kuatnya iman masyarakat Melayu Siak. Segala sendi kehidupan mereka selalu berpedoman kepada ajaran agama Islam. Sehingga nuansa keislaman juga selalu terlihat di setiap aktivitas masyarakatnya. Seperti pada senandung menidurkan anak ini.

Setelah mengucapkan kalimat tauhid, nyanyian dilanjutkan dengan memperkenalkan nabi besar Muhammad saw. Dikatakan bahwa nabi Muhammad merupakan kekasih Allah. Ini merupakan sebuah ungkapan bahwa nabi Muhammad adalah manusia mulia yang disayang oleh Allah swt. Ungkapan nabi Muhammad sebagai kekasih Allah diulang sampai beberapa kali. Hal ini dengan tujuan agar pendengaran anak terbiasa dan akrab dengan nama nabi Muhammad.

Dari kalimat-kalimat pembuka senandung menidurkan anak di atas dapat disimpulkan bahwa bahwa senandung menidurkan anak mengandung pengetahuan agama dasar yang diberikan kepada anak. Pengetahuan dasar tersebut adalah bahwa Tuhan mereka adalah Allah swt dan nabi mereka adalah nabi besar Muhammad saw. 
Tuah Talino

Tahun XIII Volume 13 Nomor 2 Edisi 6 Desember 2019

ISSN 0216-079X E-ISSN 2685-3043

Balai Bahasa Kalimantan Barat

Tidualah sayang

Tidualah nyawo

Jangan menangis

Pejamkan mato (Harniati, 2017).

Pada bait berikutnya, si ibu mulai mencoba untuk menidurkan anaknya. Tidualah sayang Tidualah nyawo. Maksudnya adalah, tidurlah sayang tidurlah belahan jiwa. Anak diistilahkan sebagai nyawa, karena begitu kasihnya seorang ibu kepada anaknya. Sehingga anak seperti nyawa dan kehidupannya bagi seorang ibu. Jangan menangis pejamkan mata. Si ibu akan membujuk anaknya untuk diam dan tenang lalu segera memejamkan mata agar cepat tertidur. Meski anak yang digendong atau diayun terkadang tidak sedang menangis, tetapi sudah menjadi kebiasaan para ibu untuk menyanyikan seperti itu.

\section{Laillahaillallah ... \\ Nabi Muhammad kekasih Allah \\ dimulai doa dengan bismillah \\ dikarang puji alhamdulillah \\ sholawat dan salam dari pada Allah \\ atas nabi-nabi ya Rasulullah (Harniati, 2017).}

Nyanyian kembali dilanjutkan dengan mengucapkan kalimat Laillahaillallah. Kalimat-kalimat tauhid dipercaya bisa menenangkan anak-anak. Sehingga ketika anak menangis, seorang ibu biasanya menenangkan anaknya dengan bacaan ayat-ayat suci Alquran. Sejak anak masih bayi, anak telah diperkenalkan dengan kalimat-kalimat tauhid. Selain itu, anak-anak juga diperkenalkan dengan tauladan umat, yakni nabi besar Muhammad saw. Bahwa nabi Muhammad adalah kekasih Allah.

Pengenalan nabi Muhammad kepada anak-anak sejak dini, dengan harapan anak-anak akan mengenal pemimpin ummat Islam tersebut dan mau meneladani sikap dan perilaku nabi Muhammad. Jika penanaman nilai-nilai agama dimulai sejak dari bayi, maka nilai-nilai tersebut akan melekat lebih cepat dan lebih lama di hati dan pikiran anak-anak.

\section{Tebang olehmu pohon delima}

Ranting dan dahan nak sayang engkau pisahkan

Pelihara olehmu hukum yang lima

Perintah dan larangan nak sayang-engkau bedakan (Harniati, 2017).

Bait di atas mengungkapkan pesan agar anak memelihara hukum yang lima. Hukum yang lima maksudnya adalah rukun Islam yang berjumlah lima. Pertama mengucapkan kalimat syahadat, kedua menunaikan sholat lima waktu, ketiga berpuasa di bulan Ramadhan, keempat membayar zakat, dan kelima melaksanakan haji bagi yang mampu. Anak diharapkan mau melaksanakan kelima rukun Islam yang menjadi pondasi bagi seorang muslim. Jika seseorang 
memegang teguh rukun Islam, maka tentu ia akan lurus dalam menjalani hidupnya.

Pesan berikutnya adalah agar anak bisa membedakan mana yang baik dan mana yang tidak baik. Anak harus bisa membedakan mana yang boleh dan mana yang tidak boleh. Sesuatu yang dilarang oleh agama dan orang tua tentulah merupakan hal yang tidak baik. Dan sesuatu yang diperintahkan oleh agama tentulah merupakan suatu hal yang baik. Oleh sebab itu, ibu berpesan pada anaknya agar melaksanakan apa yang diperintahkan oleh agama dan meninggalkan apa yang dilarang oleh agama.

\section{Nilai Pendidikan Karakter Kecerdasan}

Kecerdasan merupakan kemampuan untuk memahami informasi yang membentuk pengetahuan dan kesadaran. Pendidikan kecerdasan berhubungan erat dengan ilmu pengetahuan dalam dunia pendidikan. Pendidikan kecerdasan bertujuan agar anak dapat berpikir secara kritis, logis, dan kreatif sehingga mampu bersaing dalam lingkungan masyarakat untuk mendapatkan tempat atau kedudukan dalam kelompok masyarakat. Pengetahuan tidak hanya tersimpan dalam pikiran, tetapi mampu memberi inspirasi untuk melahirkan sesuatu yang bermanfaat bagi orang lain (Nasir, 2016:9).

\section{La ilaha illallah \\ Nabi Muhammad kekasih Allah \\ Anakku sayang cepatlah besar \\ Kejarlah ilmu dengan belajar \\ Alqur'an dan Hadits jadikan dasar \\ Penjaga diri sebagai pagar}

\section{Kasih ayah sepanjang jalan}

Kasih bunda - nak sayang - sepanjang hayat

Jika ilmu engkau peliharakan

Niscaya bahagia - nak sayang - dunia akhirat (Harniati, 2017).

Nilai-nilai pendidikan karakter kecerdasan yang ingin ditanamkan kepada anak adalah semangat belajar dan menuntut ilmu. Ilmu yang diharapkan untuk dimiliki oleh seorang anak tentu tidak hanya ilmu duniawi, tetapi juga ilmu agama. Untuk itu, Alquran dan hadits diharapkan menjadi dasar dari semua ilmu yang akan dituntut. Jika seseorang telah berpegang teguh pada Alquran dan hadits, maka hal itu akan menjadi benteng diri untuk selamat di dunia dan akhirat.

Selanjutnya jika telah menimba ilmu di sekolah maupun di luar sekolah, dalam pendidikan formal ataupun informal, ilmu yang telah diperoleh harus senantiasa dijaga dan dipelihara agar tidak hilang begitu saja. Oleh sebab itu, seorang anak harus menuntut ilmu dengan rajin dan giat. Ilmu merupakan hal yang amat penting bagi kehidupan manusia. Ilmu merupakan modal seseorang dalam menjalani kehidupan dunia dan akhirat. Dengan ilmu, kebahagiaan dunia dan akhirat akan diperoleh. Sehingga ada pepatah yang mengatakan, tuntutlah ilmu dari ayunan sampai ke liang lahat. 
Bait di atas mengungkapkan bahwa kasih sayang seorang ibu sepanjang hayatnya. Sampai si ibu meninggal, maka kasih sayangnya pada anak-anaknya tidak akan pernah habis. Seorang ibu menyayangi anaknya tanpa pamrih. Memberikan semua yang dimilikinya hanya untuk anak-anaknya. Mengurus anakanaknya sedari kecil tanpa mengenal lelah. Apapun akan dilakukan oleh seorang ibu demi kebahagiaan anak-anaknya.

Sosok seorang ibu dalam keluarga adalah malaikat tak bersayap, ibu pahlawan tanpa tanda jasa, dan ibu pemberi tanpa pamrih. Sebesar apapun seorang anak berusaha membalas jasa ibunya tidak akan pernah mampu menandingi kasih sayang dan pengorbanan ibu untuk kita anak-anaknya. Betapa besar kasih sayang seorang ibu, kasih yang tulus, hati yang lembut, dan sayang yang tiada akhir untuk kita anaknya. Ibu tak pernah lelah tuk menjaga dan merawat anaknya, ibu tak pernah berpikir untuk dirinya sendiri, anaknya adalah mutiara hatinya yang paling berharga dari apapun dan akan selalu mencintainya selamanya.

Seorang ibu sampai kapanpun akan menjadi sosok yang paling kita hormati dan banggakan serta wajib kita sayangi, karena dari ibu-lah kehidupan kita berawal. Sejak ibu mengandung kita selama sembilan bulan, dan kemudian ia mempertaruhkan nyawanya ketika melahirkan kita dan harus kembali mempertaruhkan nyawanya ketika membesarkan dan mengutamakan kebaikan untuk kehidupan kita anaknya. Ia adalah satu-satunya sosok wanita yang mungkin rela memberikan apa saja untuk anaknya. Maka dari itu, tidaklah terlalu berlebihan rasanya jika kita mencurahkan seluruh tenaga kita semampu yang kita bisa untuk membalas semua jasanya yang tak pernah bisa terbalaskan.

\section{Nilai Pendidikan Karakter Kesusilaan/Budi Pekerti}

Dasar dari pendidikan kesusilaan atau budi pekerti adalah hakikat manusia sebagai makhluk etis, yaitu makhluk yang dapat mengerti dan menyadari normanorma kesusilaan dan mampu berbuat sesuai dengan norma yang disadarinya. Pendidikan kesusilaan disebut juga dengan istilah pembentukan watak atau pembentukan kata hati (Nasir, 2016:9).

Kesumba lurik warna kebaya

Dipakaian dara seri biduan

Berbuat baik pada orang tua

Akhlak utama setiap insan

Wahai anak, kami berpesan

Kepada engkau dalam ayunan

Ibu bapakmu jangan dilawan

Jangan diikut iblis dan syetan (Harniati, 2017).

Bait di atas berisi pesan agar anak selalu berbuat baik pada orang tua. Ketika anak masih kecil, orang tua mengurusnya dengan penuh kasih sayang. Jika sakit, dirawat dan dibawa berobat. Setelah sedikit besar, dimasukkan ke sekolah dan dididik dengan ilmu agama juga ilmu pengetahuan yang berguna. Jasa dan pengorbanan orang tua terhadap anak-anaknya tentu tidak terhitung jumlahnya. 
Meskipun orang tua tidak mengharapkan balasan, tetapi kewajiban dan tugas seorang anak untuk berbakti dan berbuat baik pada kedua orang tuanya.

Jika kedua orang tua telah berusia lanjut, anak wajib mengurus dan menjaga kedua orang tuanya. Memperlakukan keduanya dengan baik dan memenuhi semua kebutuhannya. Pesan berbuat baik pada kedua orang tua ini diikuti dengan pesan untuk berakhlak mulia. Anak juga diminta untuk selalu berakhlak mulia. Bersikap baik dan berbudi pekerti luhur. Akhlak mulia ini tentu kepada siapa saja. Kepada saudara, teman, guru, dan orang-orang di sekeliling kita. Akhlak yang baik akan menjadikan seseorang disukai dan disegani.

\section{Si kurik kundi si merah saga \\ Bersulaman tekat ranggi tenunan \\ Baiklah budi pada sesama \\ Kaum kerabat mesti diutamakan (Harniati, 2017).}

Pesan berikutnya, anak diharapkan berbuat baik pada sesama. Seperti menghormati orang yang lebih tua, menyayangi yang lebih muda, dan menghargai yang sebaya. Menolong orang yang sedang kesusahan, rendah hati, tidak sombong, menjadi ciri dari budi baik. Dalam berbuat baik dan menolong sesama, diharapkan anak mendahulukan kaum kerabatnya terlebih dahulu sebelum kepada orang lain. Hal ini juga sesuai dengan ajaran Islam. Bahwa dalam memberikan bantuan, seseorang diminta untuk lebih mendahulukan sanak saudaranya dan orang-orang terdekatnya.

\section{Merdu suara biduanda raja \\ Kepala bertanjak berbaju kurung \\ Berjiran tetangga sama berjaga \\ Demikian akhlak sama sekampung (Harniati, 2017).}

Senandung menidurkan anak juga memiliki pesan agar anak dalam kehidupan bermasyarakat dan bertetangga harus saling menjaga. Hidup bertetangga harus saling menghormati, saling menghargai, dan tolong menolong. Saudara terdekat seseorang adalah tetangga yang berada di sekitar rumahnya. Oleh sebab itu, sudah sepatutnya berbuat baik pada para tetangga. Sehingga akan terjalin hubungan yang baik dan harmonis dengan orang-orang di sekitar kita.

\section{Ikanlah pari jangan dijala}

Tangkan melimpah menjadi hilang

Hasad dan dengki jangan dibela

Musuh bertambah temanpun berkurang (Harniati, 2017).

Pesan berikutnya adalah agar anak jangan mempunyai sifat hasad dan dengki. Sifat hasad dan dengki adalah sifat tercela. Yakni merasa iri hati melihat kebahagiaan dan keberuntungan orang lain. Tidak senang hati melihat orang dalam kebaikan. Sifat seperti ini harus dibuang jauh-jauh. Sebaliknya yang harus 
dimiliki adalah rasa senang melihat orang lain berbahagia atau mendapatkan kebaikan.

Sifat hasad dan dengki akan menimbulkan permusuhan. Tidak ada yang senang dengan orang yang memiliki sifat dengki. Sehingga bisa mengakibatkan orang menjauhi kita. Dengki akan mendatangkan musuh dan mengurangi teman.

\section{PENUTUP}

Senandung menidurkan anak sebagai produk budaya tidak hanya berfungsi sebagai hiburan atau sekadar menina-bobokkan sang anak. Senandung menidurkan anak mengandung nilai-nilai moral dan nilai-nilai pendidikan karakter sehingga dapat dijadikan sebagai media pengajaran nilai-nilai moral dan nilai-nilai pendidikan karakter pada anak. Selain itu, senandung menidurkan anak juga bisa menjadi penguat tali kasih sayang dan hubungan batin yang mendalam antara orang tua dan anak.

Begitu banyak manfaat yang dapat diambil dari senandung menidurkan anak maka sudah sewajarnya senandung menidurkan anak dihidupkan lagi di tengahtengah masyarakat Melayu Siak. Diharapkan dengan senandung menidurkan anak ini, anak-anak sedari kecil telah diajarkan tentang nilai-nilai kebaikan dan nilainilai pendidikan karakter. Sebab apa yang diterima anak-anak di usia yang masih dini akan lebih mudah bertahan di hati dan pikiran mereka. Sehingga setelah dewasa kelak, nilai-nilai pendidikan karakter yang ditanamkan tersebut masih melekat dan menjadi penuntun langkahnya dalam bertindak atau melakukan sesuatu.

Diberikannya pendidikan karakter pada anak sedari kecil merupakan salah satu alternatif solusi penyelesaian untuk mengantisipasi kenakalan anak dan kekerasan terhadap teman. Dengan senandung menidurkan anak dimana ketika menidurkan anak seorang ibu akan memeluk dan mendekap anaknya di dada ataupun diayun, akan menjalin kedekatan fisik dan batin antara ibu dan anak. Saat kedekatan seperti ini lalu si ibu akan menyampaikan pesan-pesan, nasihat-nasihat, dan kata-kata yang bernilai pendidikan akan masuk ke hati dan pikiran si anak. Sehingga apa yang didengar oleh anak biasanya akan tetap melekat di hati dan pikiran anak hingga ia besar nanti.

Selain itu, syair senandung menidurkan anak bisa juga dijadikan sebagai bahan pengajaran sastra di sekolah-sekolah, mulai dari tingkat SMP sampai SMA. Siswa diperkenalkan dengan syair menidurkan anak, setelah itu siswa dilatih melantunkan syair senandung menidurkan anak tersebut. Di samping mempraktikkan senandung menidurkan anak, siswa juga ditugaskan untuk memahami isi dan pesan yang terdapat di dalam syair tersebut. Diharapkan dengan memahami isi dan pesan syair, siswa dapat mengambil nilai-nilai pendidikan karakter yang terdapat di dalamnya.

Nilai-nilai pendidikan karakter yang terkandung di dalam syair senandung menidurkan anak diantarnya adalah (1) Nilai Pendidikan Karakter Keimanan dan Ketakwaan kepada Tuhan Yang Maha Esa, (2) Nilai Pendidikan Karakter Kecerdasan, (3) Nilai Pendidikan Karakter Kesusilaan/Budi Pekerti. Selain itu, salah satu ciri khas Senandung Menidurkan Anak yang dimiliki oleh masyarakat Melayu Siak adalah senandung selalu diawali dengan kalimat-kalimat tauhid dan 
puji-pujian kepada Tuhan Yang Maha Esa. Selain itu, Senandung Menidurkan Anak juga berisi salawat kepada nabi besar Muhammad saw. Hal ini menunjukkan bahwa keseharian masyarakat Melayu Siak memang dekat dengan agama Islam.

Sementara jika dilihat dari bentuk isinya, Senandung Menidurkan Anak juga berisi doa dan pengharapan orang tua terhadap anaknya. Doa dan harapan agar anaknya menjadi anak yang beriman dan bertakwa, memiliki akhlak mulia, menjadi manusia yang berguna untuk sesama, serta sukses dunia dan akhirat. Semua doa dan harapan-harapan yang baik disampaikan oleh seorang ibu melalui Senandung Menidurkan Anak.

\section{DAFTAR PUSTAKA}

Afandi, Al. (2015). "Fungsi dan Nilai Nyanyian Buaian dalam Sastra Lisan Kaili." E-Jurnal Bahasantodea. Vol. 3, No 4. Edisi Oktober 2015, 81-92.

Amir, Adreyetti. (2013). Sastra Lisan Indonesia. Yogyakarta: Andi Ofset.

Febrianti, Binar Kurniasari. (2017). "Pendidikan Karakter Anak dalam Cerita Rakyat Kanayatn Kalimantan Barat." Jurnal Tuah talino. Vol 11, Edisi Mei 2017.

Danandjaya, James. (1994). Folklor Indonesia: Ilmu Gosip, Dongeng, dan lainlain (ke empat). Jakarta: PT. Pustaka Utama Grafiti.

Hartati, Winda. "Senandung Menidurkan Anak di Siak". Direkam pada tanggal 912 Februari 2017.

Lickona, Thomas. (2012). Mendidik untuk Membentuk Karakter (Terjemahan Juma Abdu Wamaungo). Jakarta: Bumi Aksara.

Muttakin, Hidayatul. (2015). "Pendidikan Karakter dalam Lirik Tembang Dolanan Anak-Anak sebagai Bahan Ajar di Sekolah Dasar." Universitas Negeri Semarang: Skripsi.

Nasir. (2016). "Nilai Pendidikan Karakter dalam Nyanyian Rakyat Kau-Kaudara pada Masyarakat Muna.” 2016. Jurnal Humanika. No 16, Vol 16.

Neldawati, dkk. (2015). “ Nilai-Nilai Pendidikan Karakter dalam Pantun Badondong Masyarakat Desa Tanjung Bungo Kecamatan Kampar Timur Kabupaten Kampar.” Jurnal Bahasa, Sastra, dan Pengajaran. No 1, Vol 3.

Prayitno dan Afriva. (2013). "Pendidikan Dasar Teori dan Praktis". Padang: UNP.

Ratna, Nyoman Kutha. (2012). Teori, Metode, dan Teknik Penelitian Sastra. Yogyakarta: Pustaka Pelajar.

Salahuddin, Amar, dkk. (2015). "Nilai-Nilai Pendidikan Karakter Syair Nyanyian Rakyat Maondu Pojo di Kecamatan Kapur IX Kabupaten Lima Puluh Kota”. Jurnal Bahasa, Sastra, dan Pengajaran. No. 1, Vol 2. 